\title{
INVESTIGATION OF SORPTION OF CALIX[4]ARENE AND CALIX[4]RESORCINARENE TETRAALKYL DERIVATIVES WITH THE LiChrOSOrb RP 18 SURFACE BY RP HPLC AND MOLECULAR MODELLING METHODS
}

\author{
O.I.Kalchenko, S.O.Cherenok, L.I.Savonik, A.V.Solovyov*, V.V.Gorbachuk**, V.I.Kalchenko \\ Institute of Organic Chemistry, National Academy of Sciences of Ukraine, \\ 5, Murmanska str., Kyiv-94, 02660. E-mail: vik@ioch.kiev.ua \\ * Present address: Department of Chemical \& Biomolecular Engineering, University of California, Berkeley, \\ USA, CA 94720-1460 \\ ** Kazan Federal University, 18, Kremlyovskaya str., Kazan, 420008, Russian Federation
}

Key words: tetraalkoxycalix[4]arenes; tetraalkylcalix[4]resorcinarenes; reversed-phase high performance liquid chromatography; molecular modelling; complexation

Tetrahydroxycalix[4]arene, tetraalkoxycalix[4]arenes and tetraalkylcalix[4]resorcinarenes are capable to reversible adsorption on the surface of the hydrophobic support LiChrosorb RP 18 under conditions of the reversed-phase high performance liquid chromatography. The main chromatographic characteristics of tetrahydroxycalix[4]arene, a series of tetraalkoxycalix[4]arenes and tetraalkylcalix[4]resorcinarenes have been determined. It has been found that in the conditions selected (the mobile phase is acetonitrile/water, 86/14, v/v) the retention times of the compounds studied are in the wide range from $4.67 \mathrm{~min}$ to $88.0 \mathrm{~min}$ depending on the nature of the substituents in the macrocyclic skeleton of the molecule. Thus, the retention times increase with increase of the length of the alkyl substituents at the lower rim of the calixarene macrocycle. According to the molecular modelling data the most effective sorption is explained by the inclusion of LiChrosorb RP 18 octadecyl groups into the lipophilic cavity formed by the alkyl substituents at the lower rim of the macrocycle of calixarene/calixresorcinarene. Thus, the molecular cavity formed by the benzene rings remains opened for the Host-Guest complexation with the analyte molecules. This sorption of tetraalkoxycalix[4]arenes and tetraalkylcalix[4]arenes on the LiChrosorb RP 18 surface can significantly improve its resolution ability in RP HPLC analysis. The influence of replacement of tetrahydroxycalix[4]arene hydroxyl protons with the alkyl groups on the conformation of the macrocycle has been studied.

ДОСЛІДЖЕННЯ СОРБЦІї ТЕТРААЛКІЛЬНИХ ПОХІДНИХ КАЛІКС[4]АРЕНІВ І КАЛІКС[4]РЕЗОРЦИНАРЕНІВ 3 ПОВЕРХНЕЮ LiChrosorb RP 18 МЕТОДАМИ ОФ ВЕРХ ТА МОЛЕКУЛЯРНОГО МОДЕЛЮВАННЯ О.І.Кальченко, С.О.Черенок, Л.І.Савонік, А.В.Соловйов, В.В.Горбачук, В.І.Кальченко

Ключові слова: тетраалкоксикалікс[4]арени; тетраалкілкалікс[4]резорцинарени; обернено-фразна високоефективна рідинна хроматографрія; молекулярне моделювання; комплексоутворення

Тетрагідроксикалікс[4]арен, тетраалкоксикалікс[4]арени та тетраалкілкалікс[4]резорцинарени здатні до оберненої сорбиії на поверхні гідрофобної насадки LiChrosorb RP 18 в умовах обернено-фразної високоефективної рідинної хроматографрії. Визначені основні хроматографрічні характеристики тетрагідроксикалікс[4]арену, низки тетраалкоксикалікс[4]аренів та тетраалкілкалікс[4]резорцинаренів. Встановлено, що у вибраних умовах (рухома фраза - ацетонітрил/вода у співвідношенні 86/14 за об'ємом) час утримання досліджуваних сполук знаходиться в широкому діапазоні 4.67-88.0 хв в залежності від природи замісників у макроциклічному кістяку каліксарену. При цьому час утримання зростає по мірі збільшення довжини алкільних замісників на нижньому вінці каліксаренового макроциклу. Згідно з даними молекулярного моделювання найбільш ефективна сорбція відбувається за рахунок включення октадецильних груп насадки LiChrosorb RP 18 в ліпофрільну порожнину, утворену алкільними замісниками нижнього вінця макроциклу каліксарену/каліксрезорцинарену. При цьому молекулярна порожнина, сфрормована бензеновими кільцями макроциклу, залишається відкритою для комплексоутворення з молекулами аналітів. Така сорбція тетраалкоксикалікс[4]аренів та тетраалкілкалікс[4]резорцинаренів на поверхні хроматографрічної насадки типу LiChrosorb RP 18 може сутmєво поліпшити їі роздільну здатність по відношенню до аналітів в умовах обернено-фразної високоефективної рідинної хроматографрії. Досліджено вплив заміни гідроксильних протонів тетрагідроксикалікс[4]арену алкільними групами на конфрормацію макроциклічного кістяка молекули.

ИССЛЕДОВАНИЕ СОРБЦИИ ТЕТРААЛКИЛЬНЫХ ПРОИЗВОДНЫХ КАЛИКС[4]АРЕНОВ И КАЛИКС [4] PЕЗОРЦИНАРЕНОВ С ПОВЕРХНОСТЬЮ LiChrosorb RP 18 MЕТОДАМИ ОФ ВЭЖХ И МОЛЕКУЛЯРНОГО МОДЕЛИРОВАНИЯ

О.И.Кальченко, С.А.Черенок, Л.И.Савоник, А.В.Соловйов, В.В.Горбачук, В.И.Кальченко

Ключевые слова: тетраалкоксикаликс[4]арены; тетраалкилкаликс[4]резорцинарены; обращенно-фразная высокоэффрективная жидкостная хроматография; молекулярное моделирование; комплексообразование

Тетрагидроксикаликс[4]арен, тетраалкоксикаликс[4]арены и тетраалкилкаликс[4]резорцинарены обратимо сорбируются на поверхности гидрофробной насадки LiChrosorb RP 18 в условиях обращенно-фразной высокоэффрективной жидкостной хроматографии. Определены основные хроматографические 
характеристики тетрагидроксикаликс[4]арена, серии тетраалкоксикаликс[4]аренов и тетраалкилкаликс[4]резорцинаренов. Установлено, что в выбранных условиях (подвижная фраза - ацетонитрил/вода в соотношении 86/14 по объему) времена удерживания исследуемых соединений находятся в широком диапазоне 4.67-88.0 мин в зависимости от природы заместителей в макроциклическом скелете молекулы. При этом время удерживания возрастает по мере увеличения длины алкильных заместителей на нижнем ободе каликсаренового макроцикла. Согласно данным молекулярного моделирования наиболее эфрфективная сорбция происходит за счет включения октадецильних групп насадки в липофильную полость, образованную алкильными заместителями нижнего обода макроцикла каликсарена/каликсрезорцинарена. При этом молекулярная полость, сфрормированная бензольными кольцами макроцикла, остается открытой для комплексообразования с молекулами аналитов. Такая сорбция тетраалкоксикаликс[4]аренов и тетраалкилкаликс[4]резорцинаренов на поверхности хроматографрической насадки LiChrosorb RP 18 может существенно улучшить ее селективность по отношению к аналитам в условиях обращенно-фразной высокоэффрективной жидкостной хроматографии. Исследовано влияние замены гидроксильных протонов тетрагидроксикаликс[4]арена алкильными группами на конфрормацию макроциклического скелета молекулы.

Calixarenes - macrocyclic compounds available through cyclocondensation of para-substituted phenols with formaldehyde - are widely used as molecular platforms for design of specific receptors that are capable of highly selective recognition between fairly similar substrates: different cations, anions and neutral molecules $[1,2,3,4,5,6,7]$. The ability to recognize different substrates and form the Host-Guest supramolecular complexes with them is the base for wide application of calixarenes functionalized at the upper/lower rim by different groups in chemistry, physics, biology, nanotechnologies.

Calixarenes are widely used in chromatography $[8,9]$. Different substrate-receptor interactions of calixarenes with organic molecules and biomolecules are studied by the HPLC method [9]. Such investigations are important in the design of mobile or stationary chromatographic phases based on calixarenes with improved separating properties. The analysis of polycyclic compounds, isomeric nitroanilines, sulfonamides, nucleic bases, nucleosides, active pharmaceutical ingredients of Doxepin, Chloroprotixene, Flupentixol, Promethazine, Chromazine, Perazine, Levomepromazine, Chlorpromazin, Paracetamol on the calixarene based stationary phases CALTREX $^{\circledR}$ has been reported $[10,11,12,13,14,15,16,17]$.
The aim of the work was to study sorption of tetrahydroxycalix[4]arene (CA-OH), tetraalkoxycalix[4]arenes (CA-OC) and tetraalkylcalix[4]resorcinarenes (RA-C) (Scheme) on the LiChrosorb RP 18 surface in acetonitrile-water by RP HPLC and molecular modelling methods.

\section{Experimental Part}

Calix[4]arenes CA and calix[4]resorcinarenes RA were synthesized by the methods [18]. Acetonitrile was obtained from the Acros Organics company.

RP HPLC analysis (a liquid chromatograph Hitachi, Ltd., Tokyo, Japan) was performed in isocratic conditions using the chromatographic support LiChrosorb $\mathrm{RP} 18$ and $\mathrm{MeCN} / \mathrm{H}_{2} \mathrm{O}(86 / 14, \mathrm{v} / \mathrm{v})$ as a mobile phase. The research was carried out at the temperature of $26^{\circ} \mathrm{C}$. The UV detector was operated at $1254 \mathrm{~nm}$ and the flow rate was $0.6 \mathrm{ml} / \mathrm{min}$.

Lipophilicity of Log P of CA and RA was calculated by the RP HPLC method from the equation: Log $\mathrm{P}=6.195 \times\left(\log k^{\prime}\right)$. The coefficient 6.195 is the ratio of Log P value of $p$-dichlorobenzene (3.37) [19] to its $\log k^{\prime}$ determined by the RP HPLC method in this work.

The initial molecular modelling of CA, RA and their complexes was carried out by the molecular mecha-
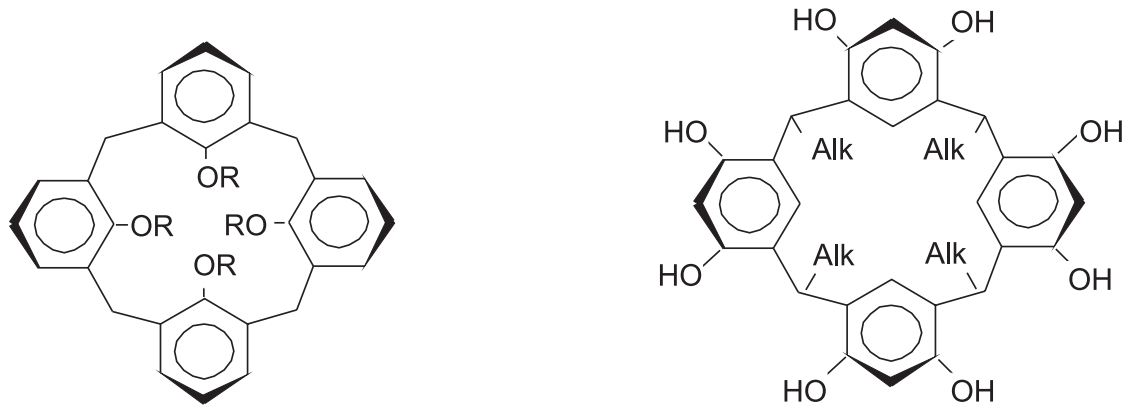

$$
\begin{aligned}
& \text { RA-C1 }\left(\text { Alk }=\mathrm{CH}_{3}\right) \\
& \text { CA-OH }(\mathrm{R}=\mathrm{H}) \quad \text { RA-C3 }\left(\text { Alk }=\mathrm{C}_{3} \mathrm{H}_{7}\right) \\
& \text { CA-OC3 }\left(R=\mathrm{C}_{3} \mathrm{H}_{7}\right) \quad \text { RA-C5 }\left(\text { Alk }=\mathrm{C}_{5} \mathrm{H}_{11}\right) \\
& \text { CA-OC6 }\left(\mathrm{R}=\mathrm{C}_{6} \mathrm{H}_{13}\right) \quad \text { RA-C7 }\left(\text { Alk }=\mathrm{C}_{7} \mathrm{H}_{15}\right) \\
& \text { CA-OC8 }\left(R=\mathrm{C}_{8} \mathrm{H}_{17}\right) \quad \text { RA-C13 }\left(\text { Alk }=\mathrm{C}_{13} \mathrm{H}_{27}\right) \\
& \text { RA-C15 }\left(\text { Alk }=\mathrm{C}_{15} \mathrm{H}_{31}\right)
\end{aligned}
$$


Table

Retention times $t_{R^{\prime}}$ capacity factors $k^{\prime}$ and lipophilicity Log P calix[4]arenes CA and calix[4]resorcinarenes RA

\begin{tabular}{|c|c|c|c|}
\hline $\mathrm{CA}, \mathrm{RA}$ & $t_{R^{\prime}} \min$ & $\mathrm{k}^{\prime}$ & Log P \\
\hline $\mathrm{CA}-\mathrm{OH}$ & 6.26 & 1.09 & 0.08 \\
\hline CA-OC3 & 28.33 & 8.44 & 5.74 \\
\hline CA-OC6 & 45.60 & 14.20 & 7.14 \\
\hline CA-OC8 & 61.00 & 19.33 & 7.97 \\
\hline RA-C1 & 4.67 & 0.56 & -1.56 \\
\hline RA-C3 & 6.17 & 1.06 & 0.16 \\
\hline RA-C5 & 9.11 & 2.04 & 1.92 \\
\hline RA-C7 & 35.58 & 10.86 & 6.42 \\
\hline RA-C13 & 76.54 & 24.51 & 8.60 \\
\hline RA-C15 & 88.00 & 28.33 & 8.99 \\
\hline
\end{tabular}

nics MM+ method, the force field was PM3. The structures obtained were optimized by the semi-empirical method (software package HyperChem, version 8) [http://www.hyper.com/Download/AllDownloads/
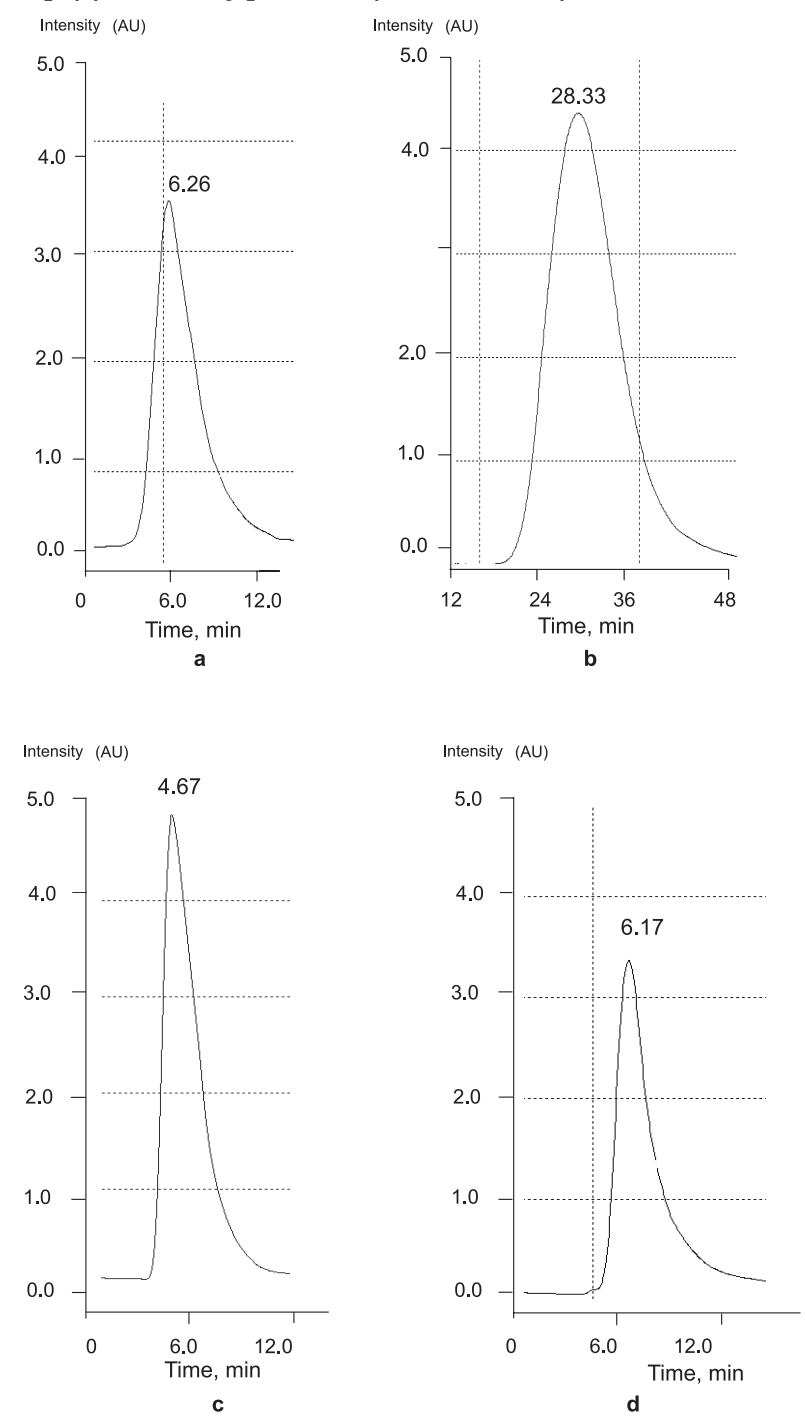

Fig. 1. Chromatograms of calixarenes $\mathrm{CA}-\mathrm{OH}$ (a) and $\mathrm{CA}-\mathrm{OC} 3$ (b), and calixresorcinarenes RA C1 (c) and RA C3 (d).
tabid/470/Default.aspx]. The RMS gradient was $0.01 \mathrm{kcal} / \mathrm{mol}$.

\section{Results and Discussion}

Calixarenes CA and calixresorcinarenes RA under conditions of the given analysis were registered on the chromatograms as sharp peaks. CA and RA retention times $t_{R}$ (in the range from $4.67 \mathrm{~min}$ to $88.0 \mathrm{~min}$ ), capacity factors $k^{\prime}$ and lipophilicity Log $\mathrm{P}$ are presented in Table.

The chromatograms of some calix[4]arenes and calix[4]resorcinarenes are presented in Fig. 1.

A linear character of adsorption isotherms of CA and $\mathbf{R A}$ reflects their reversible sorption on the LiChrosorb-RP18 support (Fig. 2, 3).

Capacity factors $k^{\prime}$ and retention times $t_{R}$ of CA, $\mathbf{R A}$ are linearly depended on the number of carbon atoms in the alkyl substituents at the lower rim of the macrocycle (Fig. 4, 5). The increase of the number of carbon atoms improves sorption on the hydrophobic LiChrosorb RP 18 surface and increases $k^{\prime}$ and $t_{R}$ values.

The values of $k^{\prime}$ and $t_{R}$ are correlated with the CA, RA molecular masses and Log P values which, in turn, are linearly depended on the number of carbon atoms in the alkyl substituents.

Such correlations confirm the hydrophobic interactions of CA, RA with octadecyl groups on the LiChrosorb RP 18 surface. Probably, intensification of hydrophobicity of the CA, RA molecules, as well as polarity of the mobile phase can lead to its irreversible sorption on the LiChrosorb RP 18 surface as it was shown in [20]. This approach can be used for physical modification of chromatographic stationary phases by the calixarene-Hosts.

The process of the analyte (A) sorption in the LiChrosorb RP18 (S) - calixarene (L) chromatographic system can be described as follow:

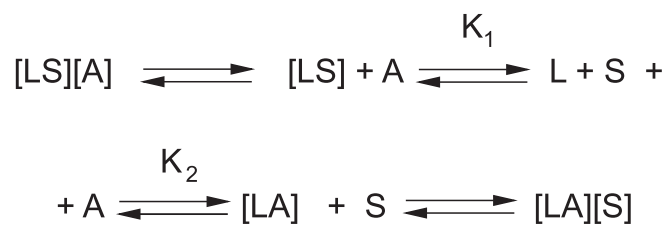

If the calixarene (L) binds with the support surface $(\mathrm{S})$ stronger than with the analyte $(\mathrm{A}),\left(\mathrm{K}_{1}>\mathrm{K}_{2}\right)$, the analyte absorbs on the calixarene modified support surface. When the analyte (A) binds stronger with the calixarene (L), then with the support surface $\left(\mathrm{K}_{2}>\mathrm{K}_{1}\right)$ the supramolecular complex (LA) will absorb on the surface.

To understand the nature of the interaction of calixarenes and calixresorcinarenes with the chromatographic support the molecular modelling of the structure of their Host-Guest complexes with siloxyoctadecane $\mathrm{H}_{3} \mathrm{SiO}\left(\mathrm{CH}_{2}\right)_{17} \mathrm{CH}_{3}$ (SOD) as a model site of LiChrosorb RP 18 has been performed. 


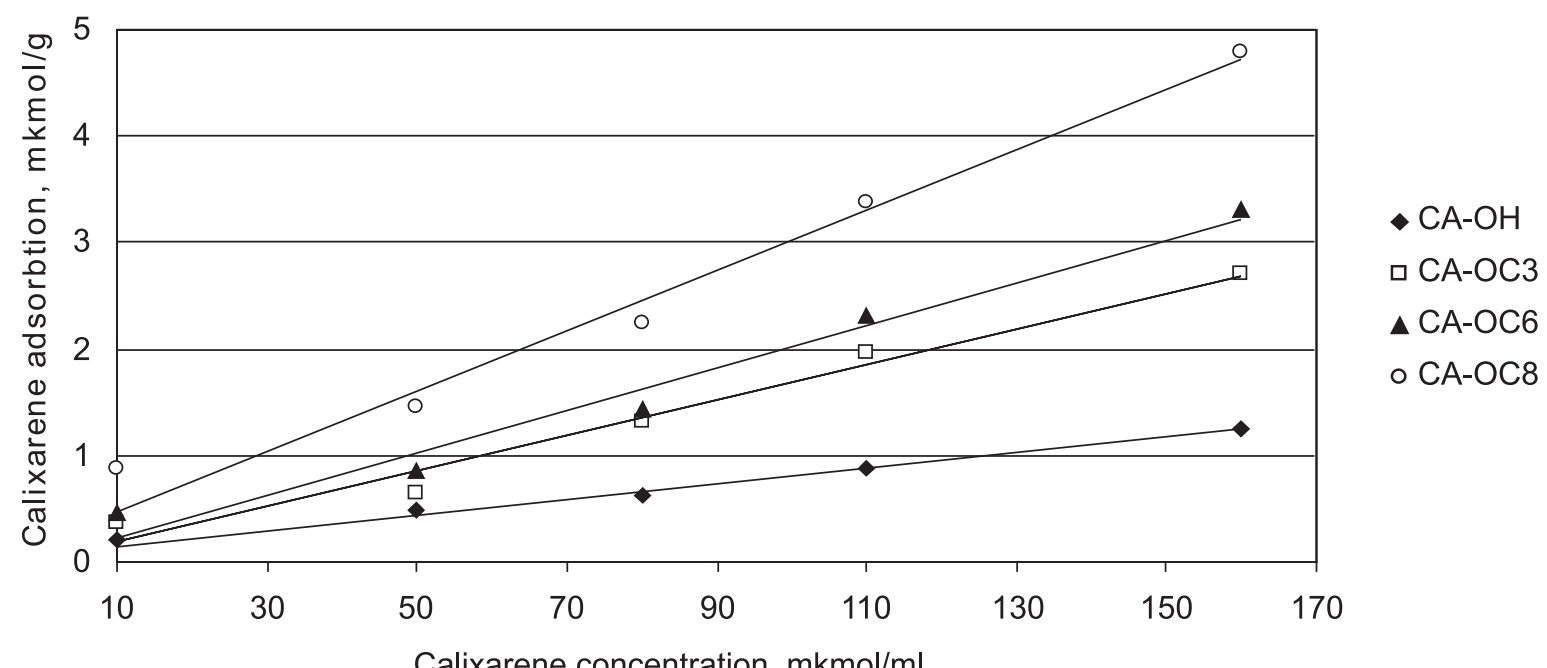

Fig. 2. Adsorption isotherm of calixarenes $C A\left(R^{2}=0.98-0.99\right)$.

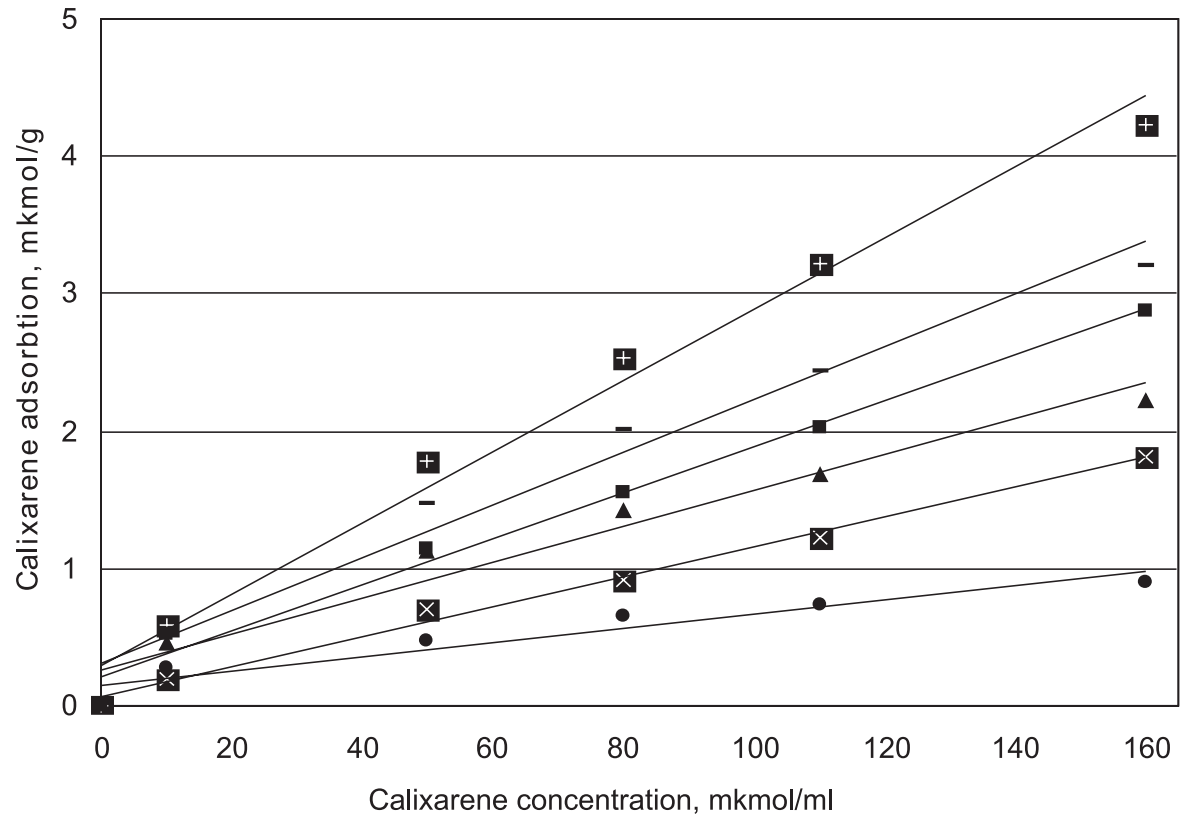

x RA-C1

- RA-C3

- RA-C5

$+\mathrm{RA}-\mathrm{C} 7$

- RA-C13

- RA-C15

Fig. 3. Adsorption isotherm of calixresorcinarenes $R A\left(R^{2}=0.98-0.99\right)$.

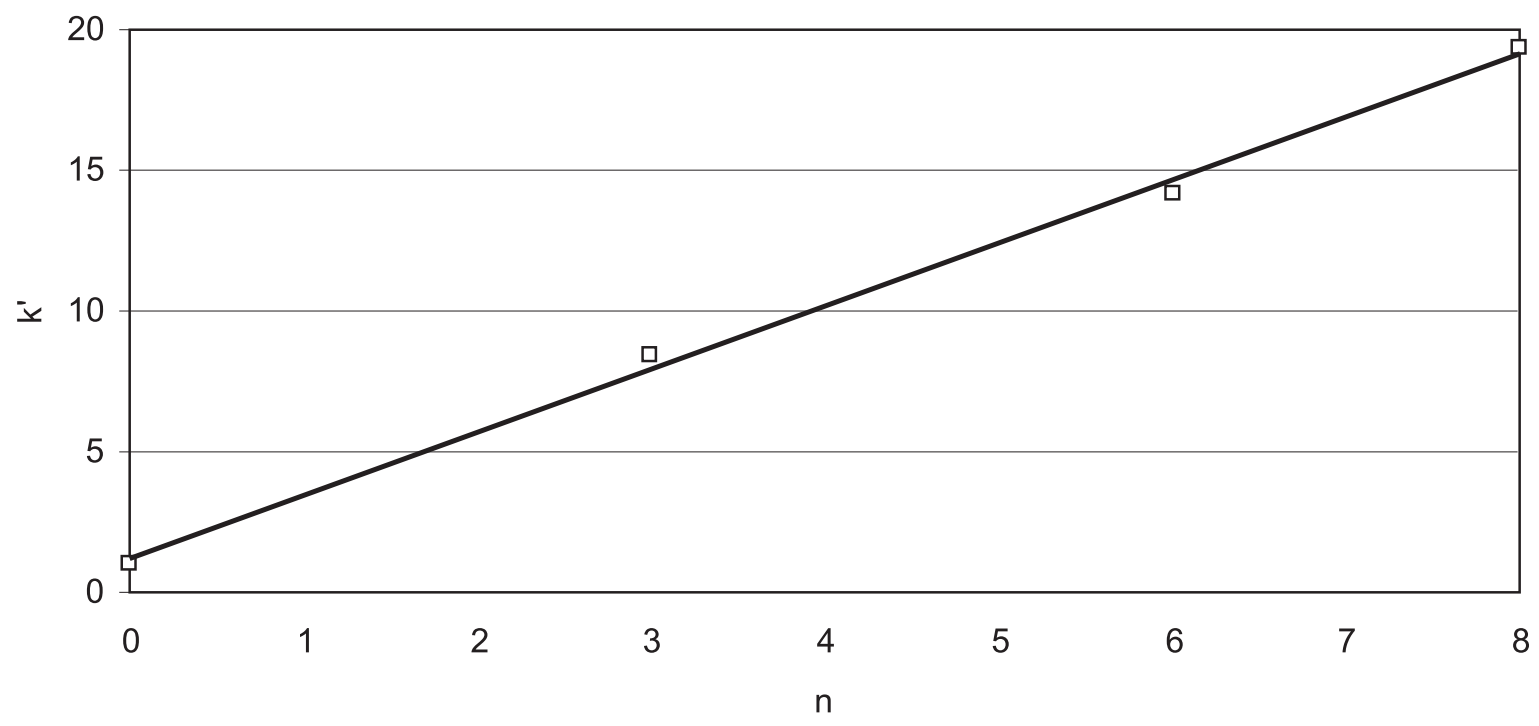

Fig. 4. Dependence of $k^{\prime}$ on the number of carbon atoms in the $C A$ aliphatic chain $\left(R^{2}=0.99\right)$. 


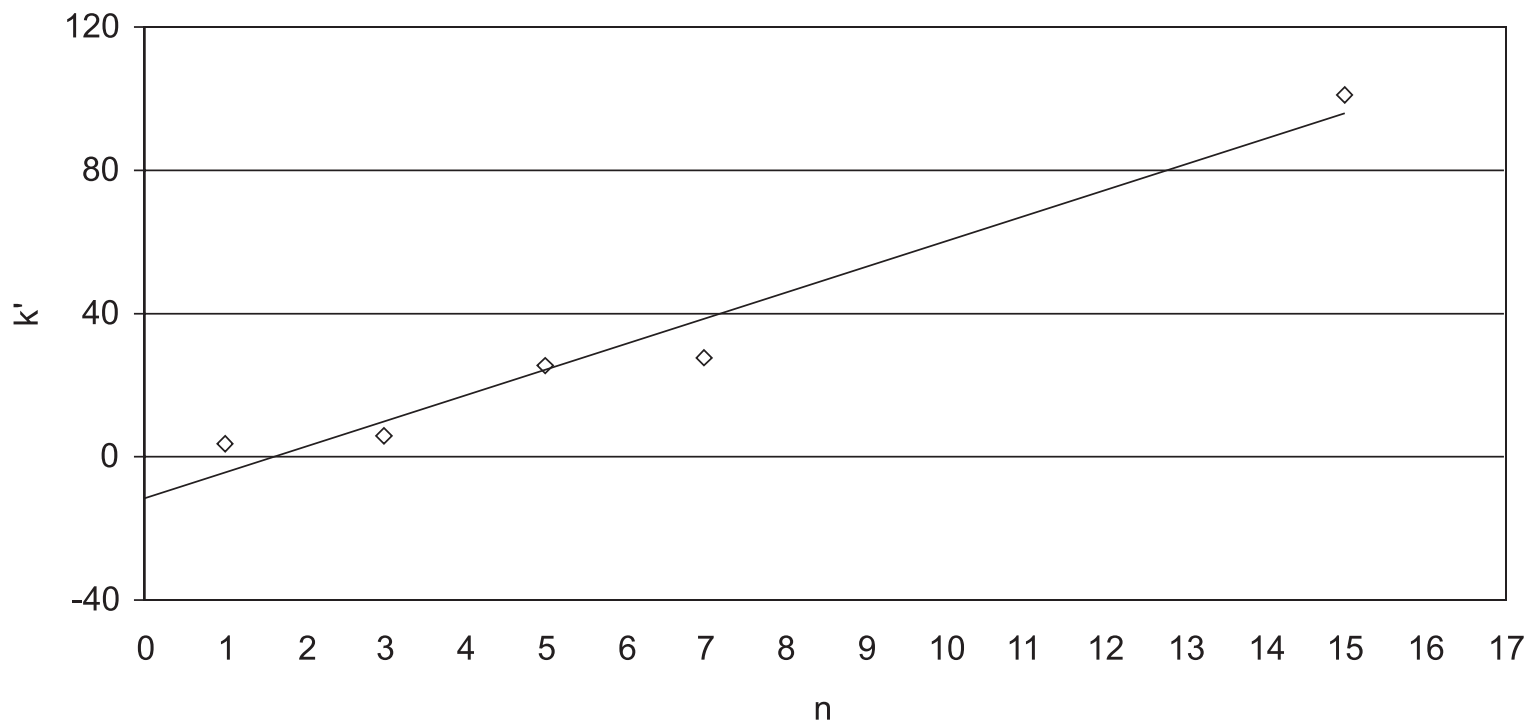

Fig. 5. Dependence of $k^{\prime}$ on the number of carbon atoms in the $R A$ aliphatic chain $\left(R^{2}=0.96\right)$.

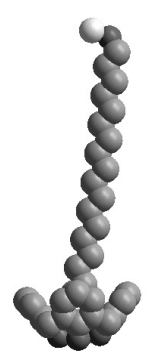

A

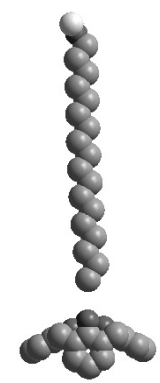

B

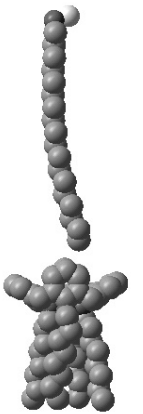

C

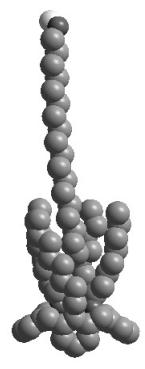

D

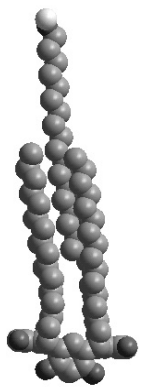

$E$

Fig. 6. Energy minimized structures of the complexes SOD with CA-OH (A,B) CA-OC8 (C,D) and RA-C15 (E).

In accordance with the modelling the tetrahydroxycalixarene CA-OH forms with SOD the complex A where the methyl group inserts in the molecular cavity formed by benzene rings of the macrocycle. The molecular cavity has the regular cone conformation stabilized by $\mathrm{CH}-\pi$ interactions of the SOD methyl group with the calixarene benzene rings, as well as by the circular system of the intramolecular hydrogen bonds between hydroxyl groups at the lower rim (Fig. 6A). In accordance with the calculations the complex B of SOD with the CA-OH lower rim (Fig. $5 B$ ) is significantly weaker compared to complex $\mathbf{A}$. The relative energies $\Delta \mathrm{E}$ of the complexes $\mathbf{A}, \mathbf{B}$ are $-8.303 \mathrm{kcal} / \mathrm{mol}$ and $-2.160 \mathrm{kcal} / \mathrm{mol}$, respectively.

Replacement of the hydrogen atoms in the hydroxyl groups of $\mathbf{C A - O H}$ to the alkyl groups changes the macrocycle conformation from the regular cone to the flattened cone. This flattening decreases the $\mathrm{CH}-\pi$ interactions in the complex $\mathbf{C}$ of SOD with CAC8 (Fig. 6C) compared to the analogous complex A. The relative energies $\Delta \mathrm{E}$ of the complexes $\mathbf{A}, \mathbf{C}$ are $-8.303 \mathrm{kcal} / \mathrm{mol}$ and $-6.073 \mathrm{kcal} / \mathrm{mol}$, respectively.

The complex D of SOD with CA-C8 is more stable $(\Delta \mathrm{E}=-9.387 \mathrm{kcal} / \mathrm{mol})$. In the complex SOD deeply penetrates in the lipophilic cavity formed by the calixarene octyl groups and holds there by the van-derWaals forces (Fig. 6D). In the RP HPLC conditions the complex $\mathbf{D}$ can be additionally stabilized by hydrophobic interactions.

The similar complex $\mathbf{E}$ is formed between SOD and the RA. The most stable is the complex E $(-11.891 \mathrm{kcal} / \mathrm{mol})$ with RA-C15 where SOD penetrates into the lipophilic cavity formed by four pentadecyl groups (Fig. 6E).

Calculation of the complexes A-E with 6000 water molecules shows only small changes in their structures compared to those calculated in vacuum.

\section{Conclusions}

Tetrahydroxycalix[4]arene, tetraalkoxycalix[4]arenes and tetraalkylcalix[4]resorcinarenes are capable to the reversible sorption on the LiChrosorb RP 18 support surface in RP HPLC conditions (the mobile phase is $\mathrm{MeCN} / \mathrm{H}_{2} \mathrm{O}, 86 / 14, \mathrm{v} / \mathrm{v}$ ). The retention times of the compounds studied are in the wide range of 4.6788.0 min depending on the nature of the substituents in the calixarene macrocyclic skeleton. The retention time increases with the lengthening of the alkyl substituent at the lower rim of the macrocycle. 
As it has been shown by the molecular modelling, the most effective sorption is observed for the complexes where the LiChrosorb's octadecyl groups are included into the lipophilic cavity formed by the alkyl substituents at the calixarene/calix[4]resorcinarene lower rim. Therefore, the molecular cavity formed by the benzene rings of the macrocycle remains opened for complexation with the analyte molecules. Such sorption of tetraalkoxycalixarenes and tetraalkylcalix[4]resorcinarenes on the LiChrosorb RP 18 support surface can significantly improve the resolution of analytes under the reversed-phase high-performance liquid chromatography conditions.

\section{References}

1. Ludwig R. Microchimica Acta. 2005, Vol. 152, pp.1-19.

2. Menon K., Sewani M. Reviews in Analytical Chemistry, 2006, Vol. 25, pp.49-82.

3. Mutihac L., Buschmann H.J. Journal of Inclusion Phenomena and Macrocyclic Chemistry, 2005, Vol. 51, pp.53-57.

4. De Fátima A., Fernandes S.A., Sabino A.A. Current Drug Discovery Technologies, 2009, Vol. 6, pp.151-170.

5. Rodik R.V., Boyko V.I., Kalchenko V.I. Current Medicinal Chemistry, 2009, Vol. 16, pp.1630-1655.

6. Cherenok S., Kalchenko V. Topics in Heterocyclic Chemistry, 2009, Vol. 20, pp.229-273.

7. Sansone F., Baldini L., Casnati A., Ungaro R. New Journal of Chemistry, 2010, Vol. 34, pp.2715-2728.

8. Boyko V.I., Yakovenko A.V., Matvieiev Yu.I., Kalchenko O.I., Shishkin O.V., Shishkina S.V., Kalchenko V.I. Tetrahedron, 2008, Vol. 64, pp.7567-7573.

9. Kalchenko O., Cherenok S., Yushchenko O., Kalchenko V. Journal of Inclusion Phenomena and Macrocyclic Chemistry, 2013, Vol. 76, pp.29-36.

10. Xiao X.Z., Feng Y.Q., Da S.L., Zhang Y. Chromatographia, 1999, Vol. 49, pp.643-648.

11. Li L.S., Da S.L., Feng Y.-Q., Liu M. Journal of Liquid Chromatography \& Related Technologies, 2004, Vol. 27, pp.2167-2188.

12. Lee Y.K., Ryu Y.K., Ryu J.W., Kim B.E., ParkJ.H. Chromatographia, 1997, Vol. 46, pp.507-510.

13. Sokoließ T., Schonherr J., Menyes U., Roth U., Jira T. Journal of Chromatography A, 2003, Vol. 1021, pp.71-82.

14. Sokoließ T., Menyes U., Roth U., Jira T. Journal of Chromatography A, 2002, Vol. 948, pp.309-319.

15. Hashem H., Jira T. Die Pharmazie, 2005, Vol. 60, pp.186-192.

16. Hashem H., Trundelberg C., Jira T. Chromatographia, 2010, Vol. 71, pp.91-94.

17. Hashem H. Chromatographia, 2010, Vol. 71, pp.31-35.

18. Arduini A., Casnati A. In Macrocycle Synthesis. A Practical Approach, Parker D. (ed.) Oxford, Oxford University Press, 1996, pp.159.

19. Hansch C., Leo A., Hoekman D.H. Exploring QSAR: Hydrophobic, Electronic, and Steric Constants (ACS Professional Reference Book) American Chemical Society, Medical, 1995, 580 p.

20. Kalchenko O.I., Lipkowski J., Nowakowski R., Kalchenko V.I., Visotsky M.A., Markovsky L.N. Journal of Chromatographic Science, 1997 , Vol. 35, pp.49-52.

Надійшла до редакції 16.06 .2014 р. 